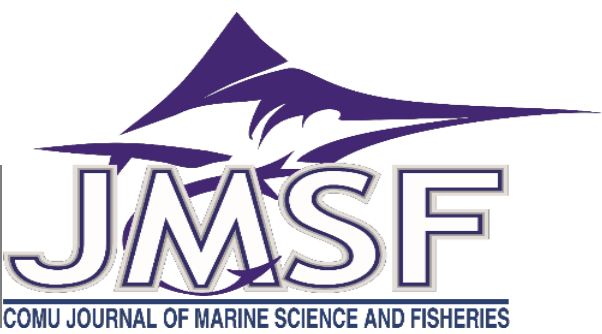

\title{
Additional Record of Sphoeroides pachygaster (Tetraodontidae) in the Aegean Sea (Fethiye, Turkey)
}

\author{
İnci Tüney Kızılkaya ${ }^{1}$, Okan Akyol ${ }^{2 *}$ \\ ${ }^{1}$ Ege University Faculty of Science 35100 Bornova, İzmir, Turkey \\ ${ }^{2}$ Ege University Fisheries Faculty 35440 Urla, İzmir, Turkey \\ Correspondent: okan.akyol@ege.edu.tr \\ Received: 16.07.2020 Accepted: 03.09.2020 \\ Inci Tüney Klzılkaya: Orcid 0000-0003-0293-6964 \\ Okan Akyol: Orcid 0000-0001-7738-2156
}

How to cite this article: Tüney Kizılkaya, İ. \& Akyol, O., (2020). Additional record of Sphoeroides pachygaster (Tetraodontidae) in the Aegean Sea (Fethiye, Turkey). COMU J. Mar. Sci. Fish, 3(2): 136-139. DOI: 10.46384/jmsf.770253

Abstract: Sphoeroides pachygaster has been well-known in the Mediterranean since the first recorded from Balearic Islands in 1979, and then, it has rapidly reached to eastern Levantine. It is widely distributed throughout the Mediterranean, especially in Italian waters, including Strait of Sicily. However, it is still rare in the Turkish seas. A single specimen of the blunthead puffer, Sphoeroides pachygaster was caught by a commercial trammel netter off Göcek, Fethiye Bay at a depth of $125 \mathrm{~m}$ on 05 July 2020. This short note contributes to the ichthyofaunal richness of the Turkish Aegean Sea with an additional record of S. pachygaster.

Keywords: Blunthead Puffer, Measurement, Additional Record, Mediterranean

\section{Ege Denizi'nde (Fethiye, Türkiye) Sphoeroides pachygaster (Tetraodontidae)'in İlave Kaydı}

Özet: Sphoeroides pachygaster, 1979'da Balear Adaları'ndan ilk kayıttan bu yana Akdeniz'de iyi bilinmektedir ve daha sonra hızla Doğu Levantin'e ulaşmıştır. Akdeniz boyunca, özellikle Sicilya Boğazı da dahil olmak üzere İtalyan sularında yaygın olarak dağılmıştır. Ancak, Türk denizlerinde hala nadirdir. Balon balığ 1 Sphoeroides pachygaster' in bir örneği, 05 Temmuz 2020'de Göcek, Fethiye Körfezi'nde 125 m derinlikten ticari bir uzatma ağ 1 teknesi tarafından yakalandı. Bu kısa not, ilave bir S. pachygaster kaydıyla Ege Denizi'nin ihtiyofaunal zenginliğine katkıda bulunmaktadır.

Anahtar Kelimeler: Balon Balığı, Ölçüm, İlave Kayıt, Akdeniz

\section{Introduction}

The blunthead puffer, Sphoeroides pachygaster (Müller \& Troschel, 1848) is a marine benthopelagic pufferfish and it usually swims at depths of 50-250 m, up to 400 m (Golani, Öztürk, \& Başusta, 2006; Froese and Pauly, 2019). S. pachygaster was originally known in the Atlantic, from Ireland to South Africa, but also the Indian Ocean. It is circumglobal in tropical and temperate seas (Froese and Pauly, 2019).

Sphoeroides pachygaster has been well-known in the Mediterranean since the first recorded from Balearic Islands in 1979 (Oliver, 1981), and then, it has rapidly reached to eastern Levantine (Golani et al., 2006). S. pachygaster is widely distributed throughout the Mediterranean, especially in Italian waters, including Strait of Sicily (Ragonese, Jereb, and Morara, 1997; Psomadakis, Ceddia, and Vacchi, 2008; Giordano et al., 2012). However, all records of $S$. pachygaster in the Mediterranean were welldocumented by Lipej, Mavric, and Paliska (2013). Newly, S. pachygaster was recorded from Northern Cyprus on March 2020 (Akbora, Snape, Ayas, \& Çiçek, 2021). It is obviously that a substantial population seems to be at present definitively established. 
In Turkish seas, Eryılmaz, Özuluğ, and Meriç, (2003) and Eleftheriou et al., (2011) reported totally four specimens of $S$. pachygaster from Saros Bay, Bozcaada Island, and Iskenderun Bay. Akyol and Aydin (2017) recorded S. pachygaster from Izmir Bay, Aegean Sea, and recently, Erguden, Ayas, \& Erguden (2020) reported a single specimen from Mersin Bay. Thus, this ichthyological note presents a sixth certain location of this species off Göcek in the Bay of Fethiye, south-eastern Aegean Sea.

\section{Material and Methods}

On 05 July 2020, a single specimen of Sphoeroides pachygaster (Figure 1) was captured by a commercial trammel net at a depth of $125 \mathrm{~m}$ off Göcek, the Bay of Fethiye (Coordinates 36 $41.866 \mathrm{~N}-28^{\circ} 57.997 \mathrm{E}$, Figure 2). The specimen was fixed in a $6 \%$ formaldehyde solution and deposited in the fish collection of Ege University, Fisheries Faculty (ESFM-PIS/2020-03).

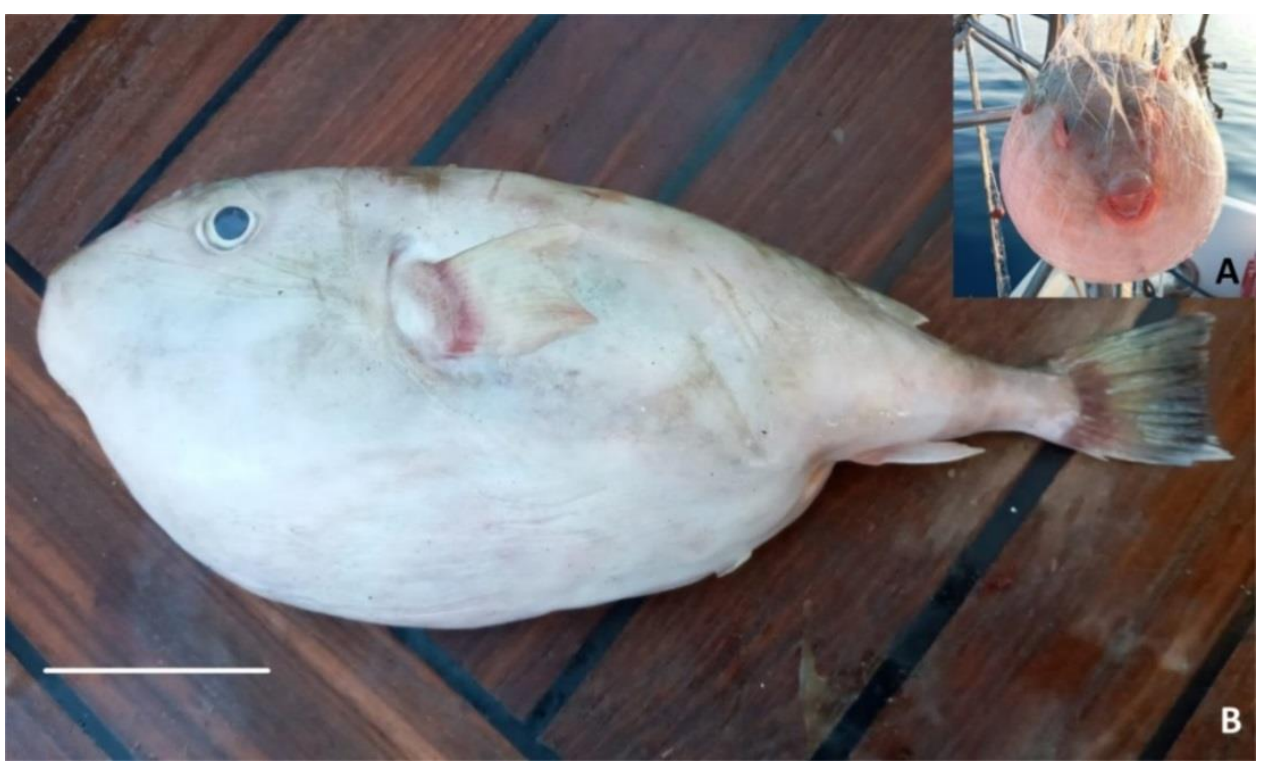

Figure 1. Sphoeroides pachygaster, captured off Göcek, Fethiye (A) distended, (B) whole body (horizontal bar: $50 \mathrm{~mm}$ )

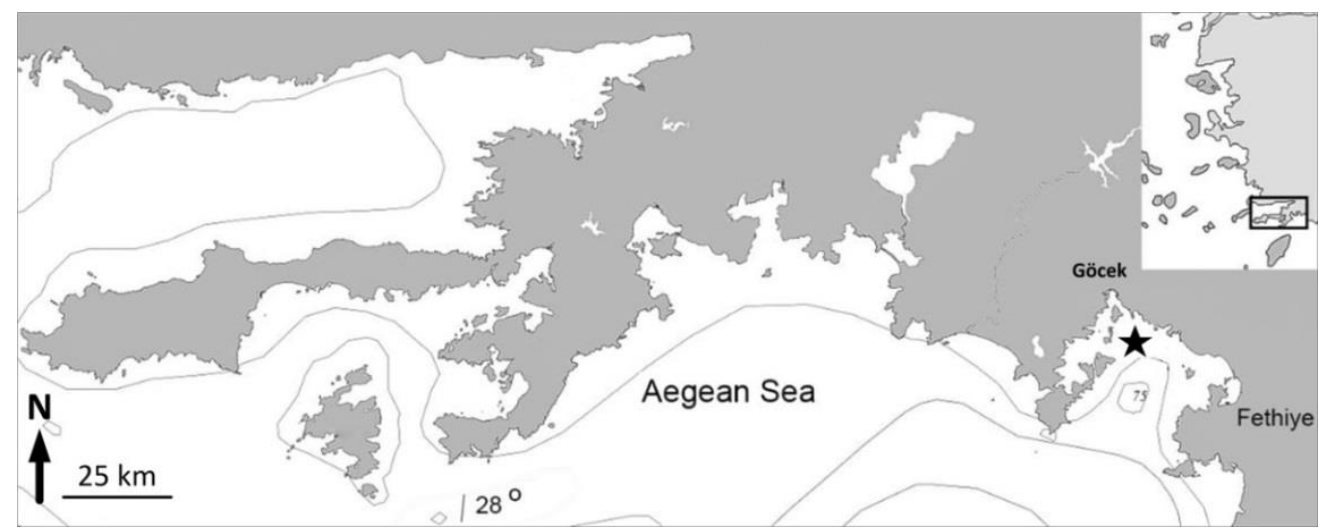

Figure 2. Sampling location (black star) of Sphoeroides pachygaster in the Aegean Sea

\section{Results and Discussion}

All measurements, counts, ratios (Table 1) and colour patterns determined are in accordance with the descriptions of Eryllmaz et al. (2003), Golani et al. (2006) and Froese and Pauly (2019). Among the tetraodontid fishes in the Mediterranean, $S$. pachygaster is uniquely of Atlantic origin. Akyol and
Aydin (2017) compiled the previous records (Golani, 1996; Zachariou-Mamalinga and Corsini, 1994; Eryılmaz et al., 2003; Peristeraki, Lazakaris, Skarvelis, Georgiadis, and Tserpes, 2006; Peristeraki et al., 2006; Zenetos, Vassilipoulou, Salomidi, and Poursanidis, 2008; Eleftheriou et al., 2011; Abdul Rahman, Galiya, and Kara Ali, 2014; Farrag, ElHaweet, Akel, and Moustafa, 2016;) and stated that 25 
specimens plus one from Northern Cyprus (Akbora et al., 2021) and one from Erdemli coast, Mersin Bay (Erguden et al. 2020) have been recorded from the Levantine Sea since 1991. All successive records from eastern Mediterranean Sea are shown in Table 2.

S. pachygaster is still considered rare in Turkish seas with only 6 findings reported earlier. However, this specimen is the seventh record since 1999 and $4^{\text {th }}$ record since 2016 in Turkish waters. This additional record with other reports in 2020 indicate a more common occurrence of this species in the Eastern Mediterranean and the Aegean Sea in recent years.

\section{Acknowledgements}

We thank fisherman Ali Akboyun for bringing the fish to our attention.

Table 1. Morphometric measurements as percentage of total length and meristic counts recorded in Sphoeroides pachygaster, captured off Göcek, Fethiye

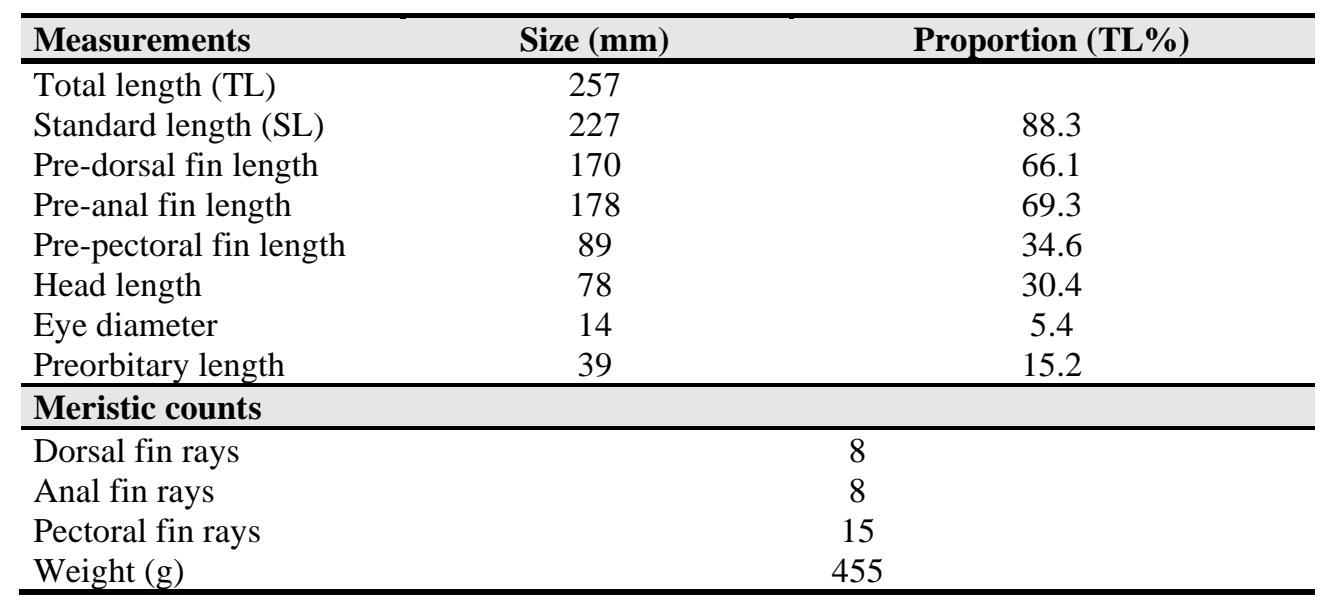

Table 2. Successive records of Sphoeroides pachygaster from eastern Mediterranean Sea

\begin{tabular}{lclccl}
\hline Location & $\begin{array}{c}\text { Depth } \\
(\mathbf{m})\end{array}$ & Record date & n & $\begin{array}{c}\text { Size } \\
\text { (mm, TL) }\end{array}$ & References \\
\hline Ashdod, Israel & 250 & 23 May 1991 & 2 & $140-183$ & Golani (1996) \\
Netanya, Israel & 360 & 02 June 1992 & 1 & 175 & Golani (1996) \\
Rhodes, Greece & 60 & Nov. 1992 & 5 & $?$ & Zachariou-Mamalinga and \\
& & & & & Corsini (1994) \\
Saros Bay, Turkey & 180 & Oct. 1999 & 1 & 167 & Eryilmaz et al. (2003) \\
Bozcaada, Turkey & 125 & May 2001 & 1 & 395 & Eryilmaz et al. (2003) \\
Sikinos, Greece & 101 & 26 Aug.2003 & 1 & $?$ & Peristeraki et al. (2006) \\
Sikinos, Greece & 104 & 12 June 2005 & 2 & $?$ & Peristeraki et al. (2006) \\
Serifos, Greece & 155 & 14 June 2005 & 1 & $?$ & Peristeraki et al. (2006) \\
Serifos, Greece & 150 & Oct. 2005 & 2 & $297-436$ & Zenetos et al. (2008) \\
Leros, Greece & 166 & 04 July 2006 & 1 & $?$ & Peristeraki et al. (2006) \\
Astypalaia, Greece & 137 & 11 July 2006 & 1 & $?$ & Peristeraki et al. (2006) \\
Karataş, Turkey & 305 & 26 Oct.2010 & 1 & 450 & Eleftheriou et al. (2011) \\
Samandağ, Turkey & 200 & 28 Oct.2010 & 1 & 187 & Eleftheriou et al. (2011) \\
Latakia, Syria & 250 & 14 Sep.2012 & 4 & $312-466$ & Abdul Rahman et al. (2014) \\
Alexandria, Egypt & $?$ & 2012-2015 & $?$ & $?$ & Farrag et al. (2016) \\
Izmir Bay, Turkey & 80 & 13 Apr.2016 & 1 & 192 & Akyol and Aydin (2017) \\
Northern Cyprus & 250 & 11 Mar. 2020 & 1 & 520 & Akbora et al. (2021) \\
Mersin Bay, Turkey & 400 & 16 May 2020 & 1 & 490 & Erguden et al. (2020) \\
Göcek, Turkey & 125 & 05 July 2020 & 1 & 257 & This study \\
\hline
\end{tabular}




\section{References}

Abdul Rahman, W., Galiya, M., \& Kara Ali, A. (2014). First record of the blunthead puffer Sphoeroides pachygaster (Osteichthyes: Tetraodontidae) in Syrian marine waters (eastern Mediterranean). Marine Biodiversity Records, 7, e31, pp. 1-3.

Akbora, H. D., Snape, R., Ayas, D., \& Çiçek, B.A. (2021). The first substantiated record of blunthead puffer Sphoeroides pachygaster (Müller and Troschel, 1848), from the coast of northern Cyprus (eastern Mediterranean). Marine Science and Technology Bulletin, 10(1): in press.

Akyol, O. \& Aydın, I. (2017). Occurrence of blunthead puffer, Sphoeroides pachygaster (Müller \& Troschel, 1848) (Tetraodontidae) in north-eastern Aegean Sea (Izmir Bay, Turkey). J Appl Ichthyol., 33: 524-526. Doi: 10.1111/jai.13277

Eleftheriou, A., Anagnostopoulou-Visilia, E., Anastasopoulou, E., Ateş, S. A., Bachari, N., El, I., ... Erguden, D. (2011). New Mediterranean biodiversity records (December 2011). Mediterranean Marine Science, 12, 491-508.

Erguden, S.A., Ayas, D., \& Erguden, D. (2020). Geographical distribution and spreading of Blunthead Puffer Sphoeroides pachygaster (Müller \& Troschel, 1848) in the Mediterranean Sea. Advances in Fisheries and Aquatic Sciences (Vol. 1). Integrated Publications. (In press).

Eryılmaz, L., Özuluğ, M., \& Meriç, N. (2003). The smooth pufferfsh, Sphoeroides pachygaster (Müller \& Troschel, 1848) (Teleostei:Tetraodontdae), new to the northern Aegean Sea. Zoology in the Middle East, 28, 125126.

Farrag, M. M. S., El-Haweet, A. K., Akel, E. H. Kh., \& Moustafa, M. A. (2016). Occurrence of puffer fishes (Tetraodontdae) in the eastern Mediterranean, Egyptan coast - filling in the gap. BioInvasions Records, 5, 47-54.

Froese, R., \& Pauly, D. (2019). FishBase. World Wide Web electronic publicaton. Retrieved from www.fshbase.org. Version (12/2019) (accessed date: 07 July 2020).

Giordano, D., Profeta, A., Pirrera, L., Soraci, F., Perdichizzi, F., Greco, S., Perdichizzi, A. \& Rinelli, P. (2012). On the Occurrence of the Blunthead Puffer, Sphoeroides pachygaster (Osteichthyes: Tetraodontidae), in the Strait of Messina (Central Mediterranean). Journal of Marine Biology, Volume 2012, Article ID 462407, 3 pages, doi:10.1155/2012/462407
Golani, D. (1996). The marine ichthyofauna of the eastern Levant- History, inventory and characterization. Israel Journal of Zoology, 42, 15-55.

Golani, D., Öztürk, B., \& Başusta, N. (2006). The fishes of the eastern Mediterranean. (259 p.) Istanbul, Turkey: Turkish Marine Research Foundation (Publicaton No. 24).

Lipej, L., Mavric, B., \& Paliska, D. (2013). New northernmost record of the blunthead pufferfish, Sphoeroides pachygaster (Osteichthyes: Tetraodontdae) in the Mediterranean Sea. Annales Series Historia Naturalis, 23, 103-114.

Oliver, P. (1981). Sobre la aparición de algunos peces raros en las islas Baleares. Boletin del Instituto Español de Oceanograia, 6, 59-64.

Peristeraki, P., Lazarakis, G., Skarvelis, C., Georgiadis, M., \& Tserpes, G. (2006). Additional records on the occurrence of alien fish species in the eastern Mediterranean Sea. Mediterranean Marine Science, 7, 61-66.

Psomadakis, P.N., Ceddia, P. \& Vacchi, M. (2008). Additional record of Sphoeroides pachygaster (Pisces: Tetraodontidae) in the Tyrrhenian Sea and notes on the distribution of the species in the Mediterranean. Marine Biodiversity Records, 1, e18, pp. 1-5. doi:10.1017/S1755267206001862

Ragonese, S., Jereb, P., \& Morara, U. (1997). Morphometric relationships of Sphoeroides pachygaster (Pisces: Tetraodontidae) of the Strait of Sicily (Mediterranean Sea). Cahiers de Biologie Marine, 38, 283-289.

Zachariou-Mamalinga, H., \& Corsini, M. (1994). The occurrence of the fish Sphoeroides pachygaster in the south-eastern Aegean Sea (Greece). Annales Musei Goulandris, 9, 479-483.

Zenetos, A., Vassilopoulou, V., Salomidi, M., \& Poursanidis, D. (2008). Additions to the marine alien fauna of Greek waters (2007 update). Marine Biodiversity Records, 1, e91, pp. 1-8. 